\title{
Problems in the Life of a University Librarian: Thomas James, 1600-1620
}

The founder of the reconstituted library at Oxford University, Sir Thomas Bodley (1545-1613), has enjoyed the praise of historians and librarians. The achievements of his librarian, Thomas James (15731629), have been less celebrated but are possibly equal in importance to those of Bodley. Evidences of the conflict between these two personalities reveal differences in objectives and approaches to librarianship. After examining four episodes at Oxford between 1600 and 1620, the author concludes that James represented a progressive position in academic library services.

$\mathrm{T}$ HE STORY of Sir Thomas Bodley's offer to restore the library at Oxford University in the early seventeenth century is a familiar one to most library historians. Much praise has been accorded Bodley (1545-1613) for his farreaching activities on behalf of the bibliographical resources of the library. Thomas James, the first librarian of the Bodleian Library, has received less attention and limited praise. Most chroniclers are content to note the significance of the printed book catalogs which he produced.

The objective of this essay is to provide some insight into Thomas James's career as an academic librarian at $\mathrm{Ox}$ ford University from 1600 to 1620 . The general approach and philosophy of James to academic librarianship will be studied in relation to the ideas of Bodley, the benefactor of the library. The relationship of the two men will be explored. To illustrate the thesis which

Mr. Davis is a student in the Graduate School of Library Science, University of Illinois. evolves from this comparison, several episodes in the life of Thomas James will be presented as examples of his contribution to the Oxford library and the profession he chose. Because of the nature of this essay, the more commonly known events of James's life will not be repeated. However, before the main thesis may be developed fully, some knowledge of the early life of Thomas James is necessary.

Although the exact date of James's birth is unknown, he was born about 1573 in Newport, Isle of Wight. ${ }^{1} \mathrm{He}$ matriculated at New College, Oxford, on January 28, 1592, and was a fellow of the college in the years 1593 to 1602 , receiving in the meanwhile his $\mathrm{BA}$ in 1595 and his MA in 1599. On May 16, 1614, he received the $\mathrm{BD}$ and $\mathrm{DD}$ degrees, perhaps in partial recognition of his achievements as a scholar-librarian.

Immediately upon finishing his undergraduate education, James began the production of scholarly works and bibliographic activity which characterized his life to the end. In the years 1598 and 1599 his translations of Italian and French works were published in Lon- 
don and Oxford. His edition of Richard de Bury's Philobiblon was printed in 1599 and included a long dedication to Bodley. Although James praised Bodley and his colleagues for reestablishing the Oxford library, there is no clue to his desire to become a librarian. Nevertheless James enjoyed, even at an early age, an excellent reputation for scholarship among his contemporaries. ${ }^{2}$ From the first, Bodley had his eye upon James to be the Keeper of his library.

Before the Bodleian Library, as it would be called in years to come, formally opened on November 8,1602 , James had been in the employ of Bodley for some months. ${ }^{3}$

Even a cursory examination of the correspondence between Bodley and James reveals the strong affection that the elder statesman held for his young librarian. Thomas Bodley was in his late fifties when he made his proposal (February 23,1598 ) to the university that he refurbish the library. ${ }^{4}$ Son of a printer, Bodley fled to Europe with his family during the reign of Queen Mary, and consequently received an education at the hands of protestant scholars in Germany and Switzerland and gained an acquaintance with several languages. With the accession of Elizabeth, Bodley's family returned to England, and he went to Magdalen College, Oxford, whence in 1563 he received his BA degree, specializing in Greek and Hebrew studies. After teaching some years, he traveled on the Continent and became proficient in Italian, French, and Spanish, and upon his return to England joined the Court. From 1585 until his request for recall and retirement from public service was granted in 1596 , he undertook various state missions of a diplomatic nature and performed well in these tasks for which he was so admirably fitted. In 1587 he married Mrs. Ann Ball, a wealthy widow; no children issued from the union. ${ }^{5}$

At the close of his life, therefore, Bod- ley determined to offer his services in a venture that would bring fame and honor to his name and to that of the university and nation. ${ }^{6}$ His proposal was accepted, and the response of his friends to support the project, both in providing books and also in gathering funds for the endowment, was successful.

Bodley, a bachelor for most of his life, was a man of various gifts and marked personality traits. ${ }^{7}$ His years as a scholar working with the details of linguistic study must have contributed to his concern for minutiae and his knowledge of the bibliography of the day. His was a classical education, and he recognized the important works in major fields. Furthermore, his years in public service must have influenced him to place a high priority on the appearance of the material in his library. He was exceedingly conscious of public relations and always strove to derive the maximum advantage out of every situation. This is seen in the meticulous way in which donors were wooed and satisfied. ${ }^{8}$

These traits, careful attention to detail and a perception of how operations appear to others, are extremely useful to the good administrator. However, Bodley combined them with a third trait. The Oxford library was in many ways the private and personal project of Thomas Bodley himself. He made the library the one passion of the last fifteen years of his life and in so doing he may have limited the development of the library. Instead of allowing for discussion in the evolution of procedures of library operation and for flexibility on the part of his staff, he exercised personal control. Until formal statutes were approved by the Crown and the university, and the endowment provisions for the library's support were accepted in 1610, Bodley was the source of all funds and he made use of this privilege to take direct responsibility for the library. ${ }^{9}$ 
Thomas James, not yet thirty when asked to be the Keeper of the Oxford library, was not interested in being a simple desk clerk for Bodley. He was basically a faculty member and his first love was research. He was concerned for the use of the materials he acquired. Not only did he want to collect for others, he wanted to avail himself of the materials and aid others in their use. As a young man, he seemed to be particularly sympathetic to the undergraduates and students below the highest rank. As a scholar more than a diplomat, he was more concerned with the general utility of the collection than he was with appearances and the impressions that were made for their own sake.

Here then are the two principal personages in the foundation of the Bodleian Library: Thomas Bodley and Thomas James. While they both placed the growth and development of the Oxford library on the highest level of priority, their personalities and modus operandi were quite different. Opinions of scholars regarding the two men vary apparently with personal biases. The traditionally minded tend to exalt Bodley, and revisionists lean toward a greater appreciation of James's role in the library's development. Here are two examples of opinion. Strickland Gibson, supporting Bodley, has written:

It must be obvious to everyone who reads Sir Thomas Bodley's letters that during the first eleven years of the library's existence he took a far larger share in its organization than did his Librarian. Although James ... had at first shown promise of being an ideal Librarian, he proved otherwise. Bodley was an exigent master, and James a careless cataloguer. ${ }^{10}$

On the other hand, George Wheeler has written concerning James,

Dr. Thomas James, Bodley's first Librarian, has perhaps scarcely received justice on his professional side at the hands either of his contemporaries or of writers of a later date. . . . To a certain extent this view is perhaps due to his having been overshadowed by the commanding personality of Sir Thomas Bodley. The latter held very decided views not only on matters of real importance but even on comparatively trivial details, and the Librarian thus became, to a large extent, merely the executive officer who carried out the instructions of the Founder. . . Perhaps, too, there has been a tendency to attribute to the Founder what really was in a great measure due to the Librarian. ${ }^{11}$

It is the thesis of this essay that Bodley and James were personalities which because of their prior training, experience, and interest were united in their love of books. But this is where the unity ends! Each had his own reasons for the practice of librarianship as he saw it. Their relationship was marked by conflict between contradictory goals. Between them they achieved a great deal. But unlike Bodley, James has not been fully appreciated.

In the following pages, four episodes in the tenure of James as Keeper of the Oxford library will be briefly studied for the purpose of understanding the relationship that he had with Bodley and appreciating his role in the library's administration. The four issues to be considered are James's initial appointment, his ideas of book selection, his shelving scheme, and his resignation.

Although Bodley had decided on James for his librarian perhaps as early as the publication of the new edition of Bury in 1599, James did not actually enter the employ of Bodley until the appointment was confirmed April 13, $1602 .^{12}$ James had, however, for several years been working with Bodley in preparing the new collection of books. Before the library was officially opened in November 1602, James tried to settle several issues with Bodley. The first involved compensation. Bodley had fixed the annual salary for the Keeper at $£ 22$ 13s. 4d. James wrote him suggesting that 
thirty or forty pounds might be more appropriate! When James hinted at leaving the library, Bodley relented and increased his compensation by four pounds per year. This was gradually raised to forty pounds per year after 1611. ${ }^{13}$ The first battle for increased financial recognition of the academic librarian was won.

Bodley's original instructions in proposing to rebuild the Oxford library also outlined the qualifications for his Keeper, whoever he would be. ${ }^{14}$ Two provisions clearly did not meet with the approval of James: the prohibition of holding a clerical appointment and the prohibition of marriage. Just two months before the library opened in November 1602 , James, with the grudging consent of Bodley, violated the regulations of the Founder. On September 14, he became rector of St. Aldate, Oxford, ${ }^{15}$ and on October 18, he married Ann Underhill. ${ }^{16}$ In 1614 and 1617, he took other church posts. Since Bodley was neither a churchman nor the marrying type (at least for the first forty years of his life), perhaps he did not realize the significance of these restrictions upon the position he outlined. By gaining Bodley's reluctant approval, James protected both his domestic and intellectual rights. Bodley, like St. Paul, apparently wanted his man to concentrate totally on the business at hand, in this case, library work. But James won out for the necessity of matrimony and the freedom to follow his intellectual interests.

A second matter which illustrates the interaction between James and Bodley involves the issue of book selection. Bodley started selecting books and manuscripts before James came to his Oxford post. Many volumes were donated by Bodley's friends and acquaintances. James I offered Bodley the privilege of selecting from his books some additions to the library-an offer that was never fulfilled. In addition to donations, Bodley had a London agent tour the book centers of Europe to purchase volumes. However, the great benefactor had a particular taste in books. ${ }^{17}$ First, he preferred large folio volumes to the smaller quarto and octavos. Second, he wanted the books to be in European or classical languages; "learned books should be written in learned languages." And third, Bodley did not want his library cluttered with English plays and almanacs, to which he referred as "baggage bookes" and "riffe raffes." Bodley's motive was probably good; he wanted to create a true scholar's library.

James did not lack enthusiasm for the classics, but he was concerned with the vernacular as well. Witness his concern for manuscripts in the university libraries and his translations into English from French and Spanish. Perhaps James saw that a growing number of English playwrights and writers were achieving stature with their continental counterparts. ${ }^{18}$ To discourage the collection of the plays of Shakespeare and Marlowe was a serious policy for the library to maintain. Eventually, of course, the library became internationally famous for precisely those materials Bodley had banned!

Manuscripts were more attractive to Bodley than printed books. It must have been in a moment of weakness when Bodley in 1610 negotiated the agreement with the Stationers' Company whereby a copy of every work printed by a member would be presented to the library. ${ }^{19}$ To Bodley's dismay and James's delight, the influx of English books slowly increased. ${ }^{20}$ Although some years were required to bring pressure upon the Company to honor its agreement, a principle was won by James which contributed to make the Bodleian Library one of the finest. James could be pleased not only because of the deposit value of this material, but because the undergraduates would have access to current English thought.

A third matter over which Bodley 
and James disagreed was the arrangement of books in the library. ${ }^{21}$ Bodley felt that the folio and larger quarto volumes should be shelved, preferably chained to desks, for relatively easy and free access. The smaller books should be kept under lock and key because of the threat of theft. Furthermore Bodley insisted on the same policy for manuscripts and printed books. Now this may have worked out well enough in 1600 when the proportion of manuscripts was much higher than in later years, and when the percentage of large folio volumes was greater than it was ten years later. But with the growing collection of medium-sized printed books, the original arrangement did not work as well.

James tried to get his chief to agree to a change, but to no avail. Upon Bodley's death in January 1613, James thought that he might be able to carry out his own plan. He separated the manuscripts and put them under lock and key, and thus they were not directly accessible to the reader. In addition, he moved the octavo volumes to open shelves. James knew the value of manuscripts and he also knew how infrequently they were being used. Progress had won again.

But not quite! James soon incurred the wrath of the Oxford archivist, Brian Twyne $^{22}$ who was engaged in research on a history of Oxford and who used the manuscripts perhaps more frequently than other scholars. Twyne made a formal complaint to the Curators of the library at the visitation of 1613 , one of the first times the Bodley statutes had been put into effect. Twyne perhaps welcomed this opportunity to attack the library and its librarian, and thus invoked the elaborate provisions that Bodley himself had laid down as to the arrangement of the library. James, yielding to pressure, was persuaded to revoke his earlier decision. He thus discovered that Bodley's spirit was still very much alive. John Rous, James's successor, was able to make the change during his tenure as Keeper. This incident shows the type of museum depository that Bodley envisioned, in contrast to the practical arrangement of James.

One other evidence of a difference in philosophy is the proposal made by James to Bodley that when the Arts portion of the new addition to the original building was completed, it be made into a library for the students of the Arts, that is, an undergraduate library. ${ }^{23}$ Bodley did not accept this proposal and the idea was not implemented at Oxford until 1883. James turned instead to his extensive subject cataloging projects as a means of aiding students.

The final episode in James's life which reflects his philosophy of mission in the library is his resignation. In 1620 James resigned from his position as Keeper of the Bodleian Library. His reason for leaving was severe bodily suffering, which may have been the case, though he lived for another nine years and was productive all the while. Yet there is some evidence that James was not appreciated by his contemporaries. Although Bodley could disagree and spar with him about library procedure, he had a certain affection for his young administrator. With Bodley's death, things probably changed somewhat.

Brian Twyne, the University Archivist, publicly wished that

Mr. James would frequent his place more diligently, keepe his houres, remove away his superfluous papers lienge scattered about the desks, and shewe himselfe more pliable and facill in directinge of the students to their bookes and purposes. ${ }^{24}$

Whether the implied can be substantiated is difficult to determine. One thing is clear. James could not have been happy bogged down in the trivial details of the profession. While still alive, Bodley dealt with these matters whether or not James wanted him to do so. James at least could concern himself 
with his Biblical studies. He was a member of one of the Oxford committees preparing the Authorized Version of the Bible in the years prior to 1611. James finally succeeded in getting Bodley to appoint an Under-Keeper in 1606 to help relieve him of some of the physical work, paging octavo volumes for patrons! Under Bodley, his duties were many, and the Founder had insisted that six hours per day in the library was reasonable; he could spend the other four hours of the work day in his own study. ${ }^{25}$

There are suggestions that in his later years as Keeper, James might have felt that he was not free to pursue those activities for which he was best suited. Of the more than twenty books that James produced between 1600 and his death, six appeared before 1613. There are none recorded from 1613 to 1623 , but eight were published between 1624 and his death in $1629 .^{26}$

He did not resign, however, until the second edition of his catalog of books in the Bodleian Library was at press. Here he arranged the titles of the 16,000 volumes in an alphabetical arrangement..$^{27}$ This was a crowning bibliographical achievement. Since the first classified catalog of 1605 , James had been at work on subject catalogs for the faculties of Theology (1607), Medicine (1610), and Law (1613). After his retirement, he completed the greatest task of all, the subject catalog for the Arts (1623). ${ }^{28}$ In a sense this fulfilled his desire to be of utmost help to the patrons of the library. Wheeler says:

He resigned the Librarianship in 1620 , and in order that readers should not be altogether deprived of the advice and assistance he had been able to give in person while he had charge of the Library, spent some part of his leisure in the compilation of a subject-catalogue intended primarily for the use of younger students. ${ }^{29}$
In an official Bodleian Library publication of 1951, the following judgment is made:

It is doubtful whether any library in Europe at this time was so well equipped with the bibliographical tools required to enable readers to make the best use of its contents. It was not without reason that a contemporary could pay tribute to "Mr $\mathrm{D}^{\text {or }}$ James the incomparably industrious and learned Bibliothecary of Oxford." 30

Whatever the deeper causes for James's resignation, his service to the library did not end and his desire to assist the academic community can hardly be questioned. A five-hundred page volume remains containing transcripts of 124 letters addressed to James. Indicating the scope of service he performed, the volume contains letters complimenting James, introducing visitors and others, asking for information from books in the library, asking for transcripts of library material, asking for help in the preparation of works for publication, and dealing with the persecution of Catholics, to name a few of the subjects. ${ }^{31}$ These copies of letters may have been left behind by James to offer a defense against the charge that he had been a liability to the library.

In summary, what can be said? Accolades have been heaped upon Sir Thomas Bodley since his imaginative proposal of 1598; his reputation has been so exalted that the labors of his librarian have been eclipsed. Episodes, however, speak for themselves. Bodley was not a librarian in the historic and professional usage of the word. Rather, he was a collector with a personal idea of the arrangement and use of the collection he sponsored as a private project for the benefit of Oxford University and England. His traditional conception of a somewhat medieval library which served a select group of classical schol- 
ars doubtless hindered the development of progressive library services. His library was to be a showpiece and an incentive to encourage further donations and endowment funds.

Thomas James was a younger man who had had recent personal experience with the problems of research and was involved in continuing study himself. $\mathrm{He}$ was aware of the changing nature of library materials and the needs of students. In short, he was both a scholar and a service-oriented librarian. $\mathrm{He}$ contrasts sharply with the aristocratic bibliophile, Bodley. The motives of neither man may be impugned. ${ }^{32}$ Without both of them, the Bodleian Library would have had a less illustrious beginning, if a beginning at all. But in a revisionist spirit, the career of Thomas James needs to be reevaluated. When that biographical study is done, Thomas James will in all probability emerge as a great academic librarian.

\section{REFERENCES}

Ed. Note: The author calls attention to Sidney L. Jackson's article, "Bodley and the Bodleian: Collections, Use, and Administration," Library Quarterly 39, 3 (July, 1969) 253-270. Jackson's article was published after acceptance by $C R L$, and although both deal with some of the same ideas, the emphasis is quite different.

1. Gordon Goodwin, "James, Sir Thomas (1573?1629)," Dictionary of National Biography (London, 1908), X, 658-660. Unless otherwise noted, biographical information on Thomas James is drawn from this source.

2. George W. Wheeler in Thomas Bodley, Letters of Sir Thomas Bodley to Thomas James, First Keeper of the Bodleian Library (Oxford, 1926), p. $x$.

3. Ibid., pp. xi-xii.

4. William D. Macray, "Bodley, Sir Thomas (15451613)," Dictionary of National Biography (London, 1908), II, 756-759. Unless otherwise noted, biographical information on Thomas Bodley is drawn from this source.

5. Falconer Madan, The Bodleian Library at Oxford (London, 1919), p. 16, cites the date of the marriage at 1597. Macray, however, in his article in the Dictionary of National Biography (p. 757) sets the date as 1587 , some ten years earlier.

6. J. N. L. Myres, "Oxford Libraries in the Seventeenth and Eighteenth Centuries," in Francis Wormald and C. E. Wright (eds.), The English Library Before 1700 (London, 1958), p. 243.

7. Gibson, p. 28 , says, "To the founding of his library Sir Thomas Bodley brought the mind of a scholar, the training of a diplomatist, and the common sense of a man of business."

8. Theodore W. Koch, "The Bodleian Library at Oxford," Library Journal, vol. 39, nos. 11, 12 (October, November 1914), p. 5 in continuously paged reprint.

9. George W. Wheeler, "The Bodleian Staff, 160012," Bodleian Quarterly Record, vol. 2, no. 23 (3rd Quarter 1919), 281. "For several years then James had sole charge of the Library, and during the whole of his term of office the greater part of the work of the Library fell to him. But if assistants were wanting there was no lack of supervisors. . . . The Founder, indeed, took such a very active part in the management of the Library that the Keeper was practically relegated to the position of an executive officer carrying out the instructions of another. The smallest admin- istrative detail was submitted for his approval before it was carried out, and full accounts had to be sent of all that was taking place in the Library."

10. Gibson, pp. 27-28.

11. George W. Wheeler, "An Early Bodleian SubjectCatalogue," Bodleian Quarterly Record, vol. 2, no. 13 (1st Quarter 1917), 17.

12. Wheeler, "Bodleian Staff," pp. 278-279.

13. Ibid., pp. 281-285. James's duties as a "clerk" were extensive and his scholarly pursuits were expected to take second place.

14. The librarian was to be "some one that is noted and knowen for a diligent Student, and in all his conversation to be trustie, actiue, and discreete, a graduat also and a Linguist, not encombred with mariage, nor with a benefice of Cure." Madan, p. 18.

15. Goodwin, p. 659.

16. Wheeler, "Bodleian Staff," p. 280.

17. The Bodleian Library in the Seventeenth Century (Oxford, 1951), p. 12.

18. Gibson, pp. 25-26.

19. Goodwin, p. 659 .

20. Bodleian Library in the Seventeenth Century, p. 13.

21. George W. Wheeler, "Free-Access in 1613," Bodleian Quarterly Record, vol. 4, no. 44 (4th Quarter 1924), 192-193.

22. A. F. Pollard, "Twyne, Brian (1579?-1644)," Dictionary of National Biography (London, 1909), XIX, 1328-1329.

23. Wheeler, "Bodleian Subject-Catalogue," p. 18 and Koch, p. 5.

24. As quoted in Koch, p. 5.

25. Wheeler, "Bodleian Staff," p. 283.

26. This estimate is made from the bibliography of James's works as listed in Goodwin, pp. 659-660.

27. Koch, pp. 5-6.

28. Bodleian Library in the Seventeenth Century, p. 14.

29. Wheeler, "Bodleian Subject-Catalogue," p. 18.

30. Bodleian Library in the Seventeenth Century, p. 12.

31. George W. Wheeler, “A Librarian's Correspondence," Bodleian Quarterly Record, vol. 6, nos. 61-62 (1929), 11-18.

32. Bodleian Library in the Seventeenth Century, pp. 9-10. "In spite of some uneasy moments and occasional threats of resignation the fruitful collaboration between Bodley and James remained unbroken until Bodley's death in January 1613." p. 10. 